\title{
IDENTIFICATION OF LOCAL CAPITAL MARKETS FOR POLICY RESEARCH
}

\author{
Glenn Rogers, Ron Shaffer, and Glen Pulver*
}

This paper reports the results of a study seeking to identify appropriate geographic units of analysis for research on bank credit for small rural non-farm businesses. Establishment of many rural banks in a historical period of local transportation modes, trade patterns, and state regulatory jurisdiction has left an institutional legacy of geographically small rural bank markets. Availability of secondary data at the state and county level, together with this historical legacy, have led in the past to adoption of county boundaries rather than a service area, as boundaries of local rural credit markets. Frequently this assumption of counties as appropriate units of analysis is not based on observed market patterns (Stolz, 1976; Glassman, 1973; Allardice and Phillis, 1984).

The banking business is local in nature due to the importance of geographic convenience (Ederington and Skogstad, 1977). A "community" market is based on the central place concept of a population center and hinterland within a hierarchy of locations defined by specialization. For this reason it is necessary to define the community markets both geographically and in terms of the specific commodity (non-farm business loans from banks) provided. The U.S. Supreme Court defined the relevant product market for commercial banks for the first time in 1963 United States v. Philadelphia National Bank, 374 U.S. 321 (see Hodgman, 1964 for a discussion of this decision).

Important geographic market heterogeneity can occur among community markets that are smaller than county geographic areas. If the county is an inappropriate unit of analysis, the samples and data aggregations used in earlier studies could be misleading for policy analysis. When counties are used as proxies for capital markets, community market heterogeneity may be averaged out through aggregation, causing county units to appear similar. In this case, local capital markets are judged to be homogeneous and local price variation among local capital

\footnotetext{
*All three authors are affiliated with the Department of Agricultural Economics at the University of Wisconsin-Madison, Madison, Wisc. Glenn Rogers is a research scientist; Ron Shaffer and Glen Pulver are professors of agricultural economics. The authors' research is funded by the College of Agriculture of the University of Wisconsin-Madison and the United States Department of Agriculture, Rural Economy Division (Cooperative Agreement X340).
}

markets, which reflects imperfections, is overlooked. Observed equal market prices across aggregated markets can be consistent with important price differentials among smaller market units. Conclusions that there is no price variation across "markets" have been used as evidence of a "competitive" market for financial market structure policy analysis (Straszheim, 1971; Lösch, 1954; Davis, 1966; Hoover, 1948; Litvak and Daniels, 1979; Lloyd and Dicken, 1972; L'Esperance, 1981; Meyer, 1967). Employment and economic growth opportunities could be lost due to inappropriate policy analysis. For this reason it is important that an appropriate unit of analysis be identified for research on local capital market policy. For a review of the use of county boundaries as market approximations, see King (1977) and Kaufman (1986).

State bank regulators and the Federal Reserve's approach to the definition of banking markets differs somewhat from other federal regulators such as the Justice Department. The decline in bank numbers during the 1930s led to an emphasis on policies aimed at limiting the bank failure rate. Bank regulators allowed the entry of new banks to markets only where they were needed and where it could be proven that they would be profitable. Michigan's Financial Institutions Act of 1945, Section 26, defined a relevant market for establishment of a new bank in terms of a minimum population of 3,000 . This policy relects what was believed empirically to be the minimum population that could profitably support a bank (Lanzillotti, 1966). The Justice Department defines a geographic market as the area in which a hypothetically unregulated monopolist could impose profitably a "small but significant and nontransitory" increase in price (Heaton, 1984, quoting Wolken, 1984).

The Federal Reserve System defines banking markets as regions in which buyers and sellers can interact without significant transaction costs. Generally, each market defined by the Federal Reserve System has a geographic trade center and adjacent areas that have close economic ties with the trade center. To identify economically integrated areas, economic and demographic data are used, including population size and density, transportation networks, commuting patterns, overlap of media coverage, natural and political boundaries, economic growth, and the banking patterns of bank customers (see Wolken 1984; Heaton, 1984; Allardice and Phillis, 1984; Horowitz, 
1977; Schweitzer, 1973).

Early studies focusing on concentration in geographic markets sometimes used a 15-mile radius around a trade center as an approximation for the market (Lanzillotti, 1966). Other studies used the geographic area from which 90 percent of a bank's deposits originated (Austin, 1969) or the area in which a bank advertised (Austin, 1977). Early studies were criticized for using political boundaries, such as counties, SMSAs, or states, rather than economic boundaries (Osborne and Wendel, 1978; Dreese, 1974; Eisenbeis, 1972; Eisenbeis, 1971; Edwards, 1965; Holland, 1964; Alhadeff, 1954). More recentstudies have used a variety of techniques, such as cluster analysis (King, 1977), econometric estimation of supply elasticities (Mathis, 1978), bank performance ratios (Salley, 1975), or demand characteristics such as two areas being linked if at least 20 percent of the employed residents of one area commute to the other (Watro, 1980). Whitehead (1980) has synthesized several of these approaches to allow for growth and change of market definition over time. Wolken (1984) has reviewed this literature and compiled an extensive bibliography for additional reading.

The study being reported addresses the research question of whether local geographic credit markets are better approximated by county boundaries or by the subcounty "community" units of analysis which lenders reported as their market. Data on 1986 lender portfolio distribution, lending experience and market growth are collected from personal interviews of all formal lenders in four Wisconsin rural counties. These data are used to test the hypothesis that community market boundaries reported by the lenders are more appropriate definitions than counties for specific types of analysis.

\section{Why Subnational Markets Exist}

The capital market is a social institution which mediates exchange of capital between net savers and borrowers for business finance. The term capital refers to both debt and equity capital used in non-farm business financing. There may be separate geographic or economic sector capital markets in which supply and demand characteristics determine the allocation and equilibrium price of capital.

The existence of a "local market" in contrast to a fully integrated "national market" is largely due to the unequal marginal cost of and access to information among markets. This is true for markets defined by economic sector and for markets defined by geographic region.

Legal restrictions and differences in access to information cause debt capital markets (dominated by commercial banks) to be largely independent of local equity capital markets (dominated by groups of friends and relatives for small businesses and specialized venture capital firms for large businesses). A business that is not well known to local lenders and that cannot provide adequate collateral as a substitute for lenders' information may be unable to obtain credit. Debt capital is generally provided with a collateral guarantee which substitutes for information on the business and borrower. Equity capital is not provided with a collateral guarantee; thus, it requires additional information on the borrower, such as is frequently available only to close friends and relatives. The lack of this type of additional information is one important reason that commercial lenders do not provide unsecured loans which friends and relatives may be willing to provide.

The existence of distinguishable geographic credit markets does not imply market imperfections. However, financial institutions in distinct markets may inadequately assess the creditworthiness of new businesses, service businesses without tangible collateral, very small businesses and very rapidly growing firms. The result is that geographic areas characterized by these types of businesses may represent a financing gap. There may be significant gaps in financing by economic sector, length of loan, availability of equity capital, size of business or geographic location. (For discussions of these issues in the literature, see Sullivan, (1979); Light and White (1979); Litvak and Daniels (1979); and Meyer, et. al. (1980)).

\section{Comparison of County Markets with Community Markets}

In contrast to using lenders or rural businesses as the primary unit of analysis, this study uses a rural bank market for non-farm business loans. County groupings of lenders are compared to community market groupings of lenders to test the hypothesis that community markets are more appropriate units of analysis than are county markets.

Any geographic area can be analyzed as a possible "market unit." This study proposes subcounty "community" geographic areas as an appropriate unit of analysis for small business credit in rural areas. Within an appropriate unit of analysis, suppliers should view demand conditions in a similar fashion, and demanders of capital should view the options for acquiring debt capital in a similar fashion.

The smallest geographic unit which has significant inter-unit variation provides the most appropriate unit of analysis. If community geographic areas are actual market units, it would be expected that groups of lenders in different community markets would be heterogeneous. If counties are market units, it would be expected that groups of lenders in different counties would be heterogeneous and community groups of lenders within a county would be 
homogeneous. The conclusion is that variation in lending behavior and lender characterization of the local market should be significant among groups of lenders in different markets.

A sample of counties, and subcounty community markets within these counties, is first selected using principal component analysis to ensure wide variation in market characteristics. The second stage of the analysis is to delineate community markets within the geographic area sampled. The third stage is to measure heterogeneity among different groupings of the lenders in the sample geographic areas. To measure heterogeneity among markets, it is necessary to define factors (composites of characteristics) that differentiate lenders and their descriptions of their local market. Factor analysis is used to define these sets of characteristics using lender responses, obtained during personal interviews, that reflect the demand and supply characteristics of local capital markets. The scores of each lender on these factor indices are used to test whether community or county groups of lenders are statistically heterogeneous. Finally, analysis of variance technique is used to test for significant variation among market groups.

\section{Selection of Sample Counties}

To reduce the cost of the field survey of rural lenders, a categorical rather than random sampling technique was chosen. Due to the availability of secondary data, a county was chosen as the primary sampling unit. The objective of county selection was to ensure, with the smallest sample possible, wide variation in characteristics that are proxies for the behavior of local capital markets and to limt other types of variation to allow for controlled statistical tests.

The primary types of comparisons desired within the sample are fast versus slow economic growth and a different sectoral mix in the local economy among services, trade (retail and wholesale), and manufacturing. The economic growth rate and sectoral mix are seen as important characteristics which are proxies for differences in local capital market behavior. These characteristics, in addition to lender behavior, are the sources of variation used to measure differences between local markets.

The second objective in selecting specific types of rural capital markets to test the research hypothesis is to limit variation between sample markets in terms of distance from financial centers, wage levels, income levels, and income distribution.

Thirty-three county level variables were chosen to measure the controlled characteristics of desired variability. Principal component analysis reduced these variables to three dimensions or principal components which cumu- latively account for 43 percent of the total variation among counties. Standardized scores were calculated for each Wisconsin non-metropolitan county using these principal components. The important variables used in this analysis are shown in Table 1.

Principal component (1) accounted for 24 percent of the total variation and represents the control variables which are income levels, income distribution, and distance to a SMSA. Principal component (2) accounts for 10 percent of the total variation and measures the rates of economic change between 1982 and 1985 . The variability of principal component (3) accounts for nine percent of total variation and measures the sectoral balance of the local economy.

A three-step procedure for selecting sample counties used the principal component standardized county scores for each of the three components. These scores are measured in standard deviation units with the state mean set equal to zero. These three steps are listed below.

1. Only the 25 non-SMSA Wisconsin counties with a Principal Component (1) score within one-half standard deviation of the statewide mean were included. This step limits differences measured by income levels, income distribution, and distance to a SMSA.

2. Only counties with a score on either Principal Component (2) or (3) of at least one standard deviation away from the statewide mean were included. Twelve counties met this criterion. This step effectively assured the widest possible variation among capital markets along the two dimensions of economic growth and economic sectoral mix.

3. One county was chosen to represent each of four county typologies identified with Principal Components (2) and (3). The four typologies and representative counties follow--

A. High scores on both Principal Component (2) and (3). This typology represents high growth counties with a high share of local wages in the retail and services sectors. The selected county, Oneida, is a tourism and "retirement" county. 1

B. High score on Component (2), but low score on Component (3). This typology represents high growth counties with a low share of local wages in the retail and service sectors. The selected county, Taylor, is a "manufacturing dependent" county.

C. Low score on both Principal Component (2) and (3). This typology represents slow 
Table 1

Characteristics of the Four Wisconsin Sample Counties

\begin{tabular}{|c|c|c|c|c|c|c|}
\hline $\begin{array}{l}\text { Variable Included by } \\
\text { Principal Component }\end{array}$ & $\begin{array}{l}\text { Oneida } \\
\text { County }\end{array}$ & $\begin{array}{l}\text { Taylor } \\
\text { County }\end{array}$ & $\begin{array}{l}\text { Lafayette } \\
\text { County }\end{array}$ & $\begin{array}{l}\text { Iowa } \\
\text { County }\end{array}$ & $\begin{array}{l}\text { State Mean } \\
\quad \mathrm{N}=52\end{array}$ & $\begin{array}{c}\text { State S.D. } \\
\mathrm{N}=52\end{array}$ \\
\hline \multicolumn{7}{|l|}{ Principal Component One } \\
\hline Control Variables & -0.30 & 0.37 & 0.25 & 0.02 & 0.00 & 1.00 \\
\hline Farmland as percent of all county land & $5.7 \%$ & $41.4 \%$ & $95.1 \%$ & $83.5 \%$ & $51.6 \%$ & $28.6 \%$ \\
\hline Distance from an SMSA (miles) & 46 & 36 & 31 & 38 & 38 & 17 \\
\hline 1985 mean weekly wage & $\$ 291$ & $\$ 289$ & $\$ 239$ & $\$ 231$ & $\$ 254$ & $\$ 37$ \\
\hline 1984 income per capita & $\$ 10,499$ & $\$ 9,840$ & $\$ 11,266$ & $\$ 9,875$ & $\$ 10,017$ & $\$ 1,288$ \\
\hline 1980 high income households & $1.8 \%$ & $3.2 \%$ & $2.9 \%$ & $3.0 \%$ & $2.4 \%$ & $0.9 \%$ \\
\hline 1980 poverty income households & $9.0 \%$ & $10.7 \%$ & $10.2 \%$ & $9.8 \%$ & $10.8 \%$ & $3.0 \%$ \\
\hline \multicolumn{7}{|l|}{ Principal Component Two } \\
\hline Economic Growth 1982-1985 & 0.64 & 1.45 & -0.97 & -3.09 & 0.00 & 1.00 \\
\hline Population 1980 to 1985 & $4.5 \%$ & $3.8 \%$ & $0.1 \%$ & $2.0 \%$ & $2.9 \%$ & $2.6 \%$ \\
\hline Total number of firms & $-8.8 \%$ & $-4.4 \%$ & $-8.0 \%$ & $-12.8 \%$ & $-10.4 \%$ & $11.5 \%$ \\
\hline Industrial employment & $2.8 \%$ & $19.8 \%$ & $6.8 \%$ & $-5.8 \%$ & $6.8 \%$ & $6.0 \%$ \\
\hline Manufacturing employment & $-6.1 \%$ & $30.4 \%$ & $64.6 \%$ & $10.9 \%$ & $12.8 \%$ & $17.8 \%$ \\
\hline Number of retail firms & $-11.5 \%$ & $-17.4 \%$ & $-16.5 \%$ & $-13.9 \%$ & $-13.9 \%$ & $5.8 \%$ \\
\hline Retail employment & $13.7 \%$ & $11.1 \%$ & $-5.8 \%$ & $-18.4 \%$ & $8.3 \%$ & $10.6 \%$ \\
\hline Number of service firms & $-5.1 \%$ & $-2.7 \%$ & $-3.3 \%$ & $-16.1 \%$ & $-4.4 \%$ & $7.4 \%$ \\
\hline Service employment & $1.6 \%$ & $24.6 \%$ & $-1.8 \%$ & $-5.0 \%$ & $3.9 \%$ & $12.9 \%$ \\
\hline Retail sales 1977 to 1982 & $30.0 \%$ & $7.5 \%$ & $40.0 \%$ & $230.4 \%$ & $39.0 \%$ & $31.8 \%$ \\
\hline \multicolumn{7}{|l|}{ Principal Component Three } \\
\hline 1985 Economic Sectoral Mix & 2.09 & -1.25 & -1.57 & 0.58 & 0.00 & 1.00 \\
\hline Wage share of manufacturing & $20.7 \%$ & $52.0 \%$ & $21.8 \%$ & $15.3 \%$ & $32.1 \%$ & $14.7 \%$ \\
\hline Wage share of retail trade & $15.6 \%$ & $6.8 \%$ & $9.8 \%$ & $10.7 \%$ & $12.4 \%$ & $4.0 \%$ \\
\hline Wage share of service sector & $22.2 \%$ & $10.9 \%$ & $3.2 \%$ & $14.7 \%$ & $13.6 \%$ & $5.1 \%$ \\
\hline Retail sales per capita 1982 & $\$ 5,169$ & $\$ 2,365$ & $\$ 1,917$ & $\$ 6,762$ & $\$ 3,578$ & $\$ 1,188$ \\
\hline
\end{tabular}

Notes: State means and standard deviations are based on all 52 non-SMSA Wisconsin counties.

Iowa county retail sales are high due to inclusion of a major mail order firm. 
growth counties with a low share of local wages in the retail and service sectors. The selected county, LaFayette, is a "farm dependent" county which has a high share of local wages in the transportation and wholesale sectors. These sectors include many businesses in the farm input sector.

D. Low score on Component (2), but high score on Component (3). This typology represents low growth counties with a high share of local wages in the retail and service sectors. The selected county, Iowa, is a "farm dependent" county with a number of tourist attractions located within commuting distance of the Madison SMSA. ${ }^{2}$

Table 1 shows the Principal Component scores for each sample county and the actual value of the characteristic variables compared to the mean of all 52 non-SMSA counties in Wisconsin. It can be seen that the two sample counties with negative (below average) standardized scores on Principal Component (2) have population and employment growth rates below the statewide average. The two sample counties with positive (above average) standardized scores on Principal Component (3) have a service sector wage share and 1982 retail sales per capita that are above the state average. Due to the sampling technique, it is possible to compare counties with extremely different economic growth rates and sectoral mixes using only these four counties.

\section{Delineation of Community Markets Within the Sample Counties}

Within the sample counties, 37 financial lending offices were identified. The sample includes 32 commercial banks, three savings and loans, and two credit unions. The term "lending office" is used because branch offices were treated as separate "lending offices" if they were able to identify the loans made at the branch office as opposed to the main office. Holding company-affililiated banks were all treated as separate lending offices.

An officer from each lending office was personally interviewed to record the lending office's loan portfolio, experience with particular business sectors, growth rate of local lending, limiting factors in business lending, and marketing efforts.

Each lending office officer was asked to identify their local geographic market area for non-farm business financing. These market descriptions were then geographically approximated by aggregating five-digit ZIP code zones. ZIP code zones are the smallest geographic unit for which information on numbers of businesses and population is available. The available information on numbers of businesses, total population, and market boundaries described by the officers was used to delineate "community" capital markets. Fifteen community markets with their primary trade centers located in the four counties were identified. The characteristics of each community market identified are shown in Table 2.

In the sample rural areas of Wisconsin, over 90 percent of non-farm businesses have less than 10 employees. Over 65 percent are in the trade (retail and wholesale) or service sectors. These businesses view their local bank as their primary source of debt financing. Local banks make over 90 percent of their NFB (non-farm business) loans within 15 miles of the bank office. The reported market area for some lending institutions is even smaller than a 15 mile radius and generally falls within the county boudaries. This is an indication that many businesses and lenders perceive spatial boundaries that are smaller than the county boundaries in relation to their "local market."

\section{Factors Used to Measure Market Heterogeneity}

The empirical question is: which unit, county, or community is a more appropriate approximation of a local capital market for policy analysis? To test which geographic grouping of lending offices is most appropriate, four factor scales are constructed to characterize each lender. Mean factor scores of all lenders in a particular geographic grouping are used to characterize the geographic market. Instead of comparing market heterogeneity using many individual variables, these four factors are used in an analysis of variance to compare variation among geographic groupings of lenders.

It is assumed that the underlying casual structure is factorial in nature. The variation in the observed variables, based on survey responses, is assumed to be due to the following four underlying factors:

1. Supply side lending effort to non-farm business,

2. Demand side growth in the local market,

3. Sectoral mix in the demand side of the local market, and

4. Sectoral mix in the supply side of the local market.

Economic theory concludes that supply and demand factors interact within a market to mutually determine the market result. The initial sample selection for this study is based on the assumption that variation in behavior of local capital markets is correlated with differences in economic growth and local sectoral mix. A mismatch within the local 
Table 2

Market Characteristics and Average Lender Factor Scores by County and Community Groupings

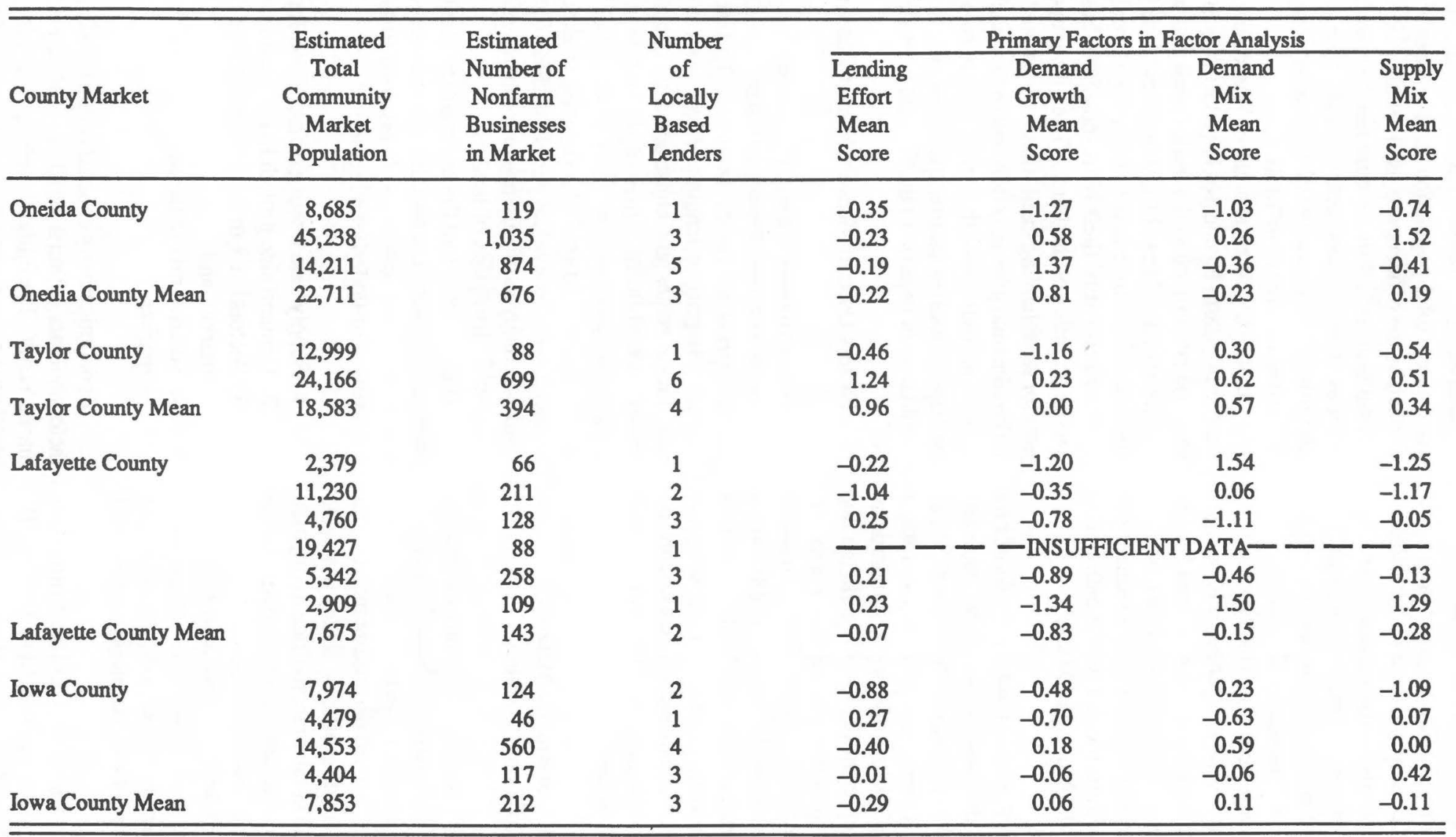

Notes: Population for each market is estimated using five-digit ZIP code zone aggregations.

Nonfarm business estimate based on state unemployment compensation data and survey responses.

Locally based lenders have the primary lending office physically located in the subcounty market.

Factor scores reported for each market are the mean of all locally based lenders.

County mean factor scores are for all lenders physically located in the county.

Scores represent standard deviations from the sample average which is standardized to zero. 
market in terms of either aggregate supply and demand or sector specific supply and demand will produce a capital market imbalance. If a geographic area is identifiably different in any of these factors, then evidence exists that the geographic area should not be aggregated into a larger area for analytical purposes. Such an aggregation would average out the differences that are critical to identifying how a local capital market functions.

A principal component analysis was used to extract four factors using 32 variables from the lender survey. The varimax orthogonal transformation method was used to rotate the initial factor solution to simplify interpretation of the final factors (Kim and Mueller, 1978). ${ }^{3}$ Factor scores were calculated for each lender for each factor using this rotated solution. The survey variables correlated with each factor are described below in Table 3.

\section{Variables Included in Factor Analysis Based on the Lender Survey}

The four underlying factors determine the characteristics of the local market as measured by specific variables in the lender survey. Variables reflecting lender characteristics and lender characterization of the demand side of the local market were collected from all lending offices based in the four sample counties. The individual variables included in the factor analysis were chosen to reflect demand and supply side characteristics as well as growth and sectoral mix characteristics. The following is a description of the variables included in the analysis of Table 3.

Number of lenders is a proxy for lending diversity in the local market. Locally based lenders are those lenders physically located in the self-identified community bank market. Total number of lenders is the sum of locally based lenders and lenders physically located outside the market but active in non-farm business financing in the local market.

Lender focus is measured in four ways. The first is self-perception; the second is the portfolio share by business stage; the third is the portfolio share by economic sector, and the fourth is the portfolio share allocated to customers with whom the lender has had a working relationship shorter than one year. Self-perception is measured by two dummy variables based on what the lender reported as the institution's major lending focus. The possible responses for lending focus were farming, non-farm businesses, and real estate. Portfolio share is measured as the percentage of the lender's total local NFB (non-farm business) loan volume.

Non-farm loan demand is measured in two ways. The first is a dummy variable which equals one if the lender stated that there is adequate local commercial and industrial demand for placing all the funds desired. The second measure is the two-year percentage growth in the lender's non-farm business loan portfolio during 1985 and 1986.

Local share of non-farm business loans is measured by the percentage of the lender's total non-farm business loan volume that is allocated to businesses located within 15 miles of the lender's office.

Changes in the local market are measured by four dummy variables which equal one if the lender responded "yes" and zero if they responded "no" to the following questions regarding change in the local market during 1985 to 1986: "Have traditional financial intermediaries, not physically present, increasingly been providing financing locally? Have your competitors been offering new product lines? Have your competitors been taking more risk? Have your competitors been offering easier terms?"

Lending efforts of the lender during 1986 are measured by four dummy variables coded "one" if they are making efforts and "zero" if they are making no effort. The four categories of effort are:

1. efforts to expand their market area geographically,

2. efforts to help people get started in business locally,

3. efforts to bring new businesses to the local market area, and

4. efforts to expand financing to existing local businesses and customers.

Lender characteristics are measured by lender ratios and perceptions of the lender as indicated by reasons that businesses refuse financing offered by the lender. "Loan approval rate" is the percentage of total non-farm business loan requests that are approved by the lender. "Approval rework rate" is the percentage of all approved loans that are not approved as presented but only after reworking the request with the customer. "Non-local firm request" is the number of times during 1986 that the lender was approached for business financing by someone from outside their normal market area. Lender asset size is measured in millions of dollars. "Interest rate too high" and "requires collateral" are two lender characteristics that are measured with a Likert scale variable. Lenders were asked whether borrowers refused financing they offered because the interest rate was too high or personal collateral was required. Responses to these questions were coded as NEVER $=1$, RARELY $=2$, SOMETIMES $=3$, FREQUENTLY $=4$, and ALWAYS $=5$.

Business characteristics are measured by three Likert scale variables that are scaled in the same manner as the 
Table 3

Factor Score Weights

Orthogonal Transformaiton with Varimax Solution

Based on Survey of Rural Lenders

Individual Lender as the Unit of Observation

\begin{tabular}{|c|c|c|c|c|c|}
\hline \multirow[b]{2}{*}{ Variables in Factor Analysis } & \multirow[b]{2}{*}{ Units } & \multicolumn{4}{|c|}{ Primary Factors Identified in Factor Analysis } \\
\hline & & $\begin{array}{l}\text { Lending } \\
\text { Effort }\end{array}$ & $\begin{array}{l}\text { Demand } \\
\text { Growth }\end{array}$ & $\begin{array}{l}\text { Demand } \\
\text { Mix }\end{array}$ & $\begin{array}{l}\text { Supply } \\
\text { Mix }\end{array}$ \\
\hline \multicolumn{6}{|l|}{ Number of Active Lenders } \\
\hline Locally based & number & 0.08 & 0.13 & & 0.10 \\
\hline Total & number & & 0.14 & 0.05 & 0.11 \\
\hline \multicolumn{6}{|l|}{ Lender Focus } \\
\hline Real estate & dummy & -0.08 & 0.10 & & -0.05 \\
\hline Non-farm & dummy & 0.11 & & & \\
\hline Startup firms & dollar share & & 0.18 & & -0.07 \\
\hline Ownership transition & dollar share & & & 0.17 & -0.06 \\
\hline Retail sector & dollar share & -0.13 & & & -0.19 \\
\hline Wholesale & dollar share & & & & 0.18 \\
\hline Manufacturing & dollar share & & & 0.12 & 0.15 \\
\hline Services & dollar share & 0.16 & -0.06 & -0.12 & \\
\hline Construction & dollar share & & 0.17 & -0.05 & 0.05 \\
\hline New NFB customers & percentage & & 0.18 & -0.06 & \\
\hline \multicolumn{6}{|l|}{ Non-farm Loan Demand } \\
\hline Adequate demand & dummy & 0.08 & 0.05 & -0.14 & \\
\hline Two-year percent growth & percentage & 0.05 & & -0.07 & 0.16 \\
\hline NFB loans within 15 miles & percentage & & -0.16 & & \\
\hline \multicolumn{6}{|l|}{ Changes in Local Market } \\
\hline Non-local activity & dummy & & 0.11 & 0.05 & \\
\hline New product lines & dummy & & & & 0.22 \\
\hline More risk taking & dummy & 0.07 & -0.05 & 0.14 & \\
\hline Easier terms & dummy & & & 0.20 & \\
\hline \multicolumn{6}{|l|}{ Lending Efforts } \\
\hline Expand geographically & dummy & & & & -0.10 \\
\hline Startup firms & dummy & 0.15 & & -0.08 & -0.06 \\
\hline Bring in new business & dummy & 0.11 & 0.09 & -0.07 & -0.08 \\
\hline Expand to local firms & dummy & 0.17 & & & -0.09 \\
\hline \multicolumn{6}{|l|}{ Lender Characteristics } \\
\hline Loan approval rate & percentage & -0.07 & -0.16 & -0.08 & 0.16 \\
\hline Approval rework rate & percentage & 0.06 & & 0.15 & -0.09 \\
\hline Non-local firm request & dummy & 0.06 & 0.10 & 0.13 & \\
\hline Asset size (millions of dollars) & dollars & & 0.05 & 0.14 & 0.09 \\
\hline Requires collateral & Likert scale & & 0.06 & 0.18 & \\
\hline Interest rate too high & Likert scale & & & 0.06 & 0.13 \\
\hline \multicolumn{6}{|l|}{ Business Characteristics } \\
\hline Too much debt & Likert scale & -0.16 & 0.05 & -0.05 & \\
\hline Insufficient equity & Likert scale & -0.17 & & -0.06 & \\
\hline Insufficient collateral & Likert scale & & 0.05 & & -0.13 \\
\hline
\end{tabular}

lender characteristics measured by the Likert scales described above. The business characteristics are measured by lender reponses identifying the major problems prevalent in those business financing requests denied by the lender. One reason lenders deny loan requests is that the businesses incur too much debt. A second reason is that the firms have insufficient equity. The third reason for lender denial is that the firm has insufficient collateral. 
Factor (1) was identified as representing Supply Side Lending Effort to non-farm businesses. These lenders consider themselves to be non-farm business lenders. High scores on factor (1) represent financial offices that have a high proportion of their non-farm business loans in the service sector and a low share in retail. These lenders are more aggressive in financing startup firms and local firms and are active in bringing new firms into their market. Lenders reported that they rarely denied additional credit to their customers because the firms have too much debt and too little equity.

Factor (2) was identified as representing Demand Side Growth. High scores on factor (2) represent financial offices which lend to new businesses and customers with which they have had only a short business relationship. The non-farm business loans of these lenders tend to be concentrated in the construction sector, which is related to their real estate lending focus. These lenders have a lower overall approval rate for local business financing requests. The local market boundaries are more permeable for these lenders, as they lend to a broader geographic market, and non-local lenders are increasingly active in their local markets. The markets in which these lenders are located have a higher total number of lenders active in the market, and nonlocal lenders are becoming increasingly active locally. Active lenders include both locally based lenders in the community market itself and non-local lenders based outside the community market but actively lending into the market.

Factor (3) identifies Demand Side Business Mix. The portfolios of these lenders have an above average share in manufacturing and a below average share in services. A high proportion of the non-farm business loans of this group tend to be for businesses in the "ownership transition" stage which could indicate a high rate of business ownership turnover in the local market. To increase their lending, these lenders are offering easier terms and taking more risks. A high proportion of loan approvals are granted after reworking the proposal with the customer, indicating more complex loan evaluation requirements. These lenders, who have a tendency to be above average size in terms of assets, are more frequently approached by borrowers from outside their local market. Borrowers sometimes refuse financing from these lenders due to excessive collateral requirements which may reflect the risky nature of the loan requests.

Factor (4) identifies Supply Side Lending Mix. High scores on factor (4) represent growing markets in which a high proportion of non-farm business lending is in manufacturing and wholesale, which indicates lending to manufacturing and farming. These lenders have a low share of their loans in the retail sector and their competitors are actively expanding their financial product lines. Businesses sometimes refuse financing from these lenders due to the high interest rates charged; hence, lending is limited by the suppliers within the local market.

All the lenders were grouped by community and then, subsequently, by county market unit. Mean factor scores were then calculated for each factor and each geographic group of lenders. Mean factor scores for each geographic unit are presented in Table 2. These mean factor scores were used as dependent variables in analysis of variance ANOVA to determine statistical differences among market groupings.

\section{Capital Market Identification Using Analysis of Variance}

The empirical test for appropriateness of a geographic grouping of lenders as a market proxy is whether the geographic grouping of lenders accounts for a significant proportion of the total variation among lenders. The types of variation that distinguish lenders have been reviewed in the previous section. Using the lender factor scores, both county grouping and community grouping of lenders are statistically analyzed using one-way ANOVA. The only independent variable used in the ANOVA is the market grouping. ANOVA is used to determine statistically whether the differences among lenders are significantly correlated with either the county or community geographic market units.

Table 4 presents the $F$-ratios from the ANOVA using both county and community market groupings. As can be seen from Table 4, factors (1) and (2) indicate that county groupings are appropriate, while factors (2) and (4) indicate that community groupings are appropriate. The low $F$-ratio for the factor (3) ANOVA indicates that neither grouping is statistically significant.

ANOVA, using factor (1), Supply Side Lending Effort, indicates that the county grouping is statistically significant but that the community grouping is not. Factor (1) reflects the non-farm business lending effort of local lenders. These lenders are more likely to claim non-farm business lending as their primary investment focus, lend more to service sector businesses rather than to retail firms only, and be willing to extend more debt to individual firms. The conclusion from this ANOVA is that aggressive lending behavior occurs at the county level. Aggressive lenders lend outside the traditional local geographic market, which expands their effective market to the county.

ANOVA, using factor (2), Demand Side Growth, suggests that community units of analysis are appropriate but that statistical differences exist at the county level as well. A high score on factor (2) reflects the presence of 
Table 4

F-ratios for ANOVA on County and Community Market Groupings

Based on Lenders as Unit of Observation

\begin{tabular}{lcccc}
\hline \hline & \multicolumn{3}{c}{ Primary Factors Identified in Factor Analysis } \\
\cline { 2 - 5 } & $\begin{array}{c}\text { Lending } \\
\text { Effort }\end{array}$ & $\begin{array}{c}\text { Demand } \\
\text { Growth }\end{array}$ & $\begin{array}{c}\text { Demand } \\
\text { Mix }\end{array}$ & $\begin{array}{c}\text { Supply } \\
\text { Mix }\end{array}$ \\
\hline County Market Grouping & 3.196 & $\mathbf{5 . 4 2 0}$ & $\mathbf{1 . 0 1 6}$ & $\mathbf{0 . 6 2 4}$ \\
$\quad \begin{array}{l}\text { Fratio } \\
\text { Significance level }\end{array}$ & $(0.038)$ & $(0.004)$ & $(0.400)$ & $(0.605)$ \\
Community Market Grouping & & & & \\
F-ratio & 0.551 & 2.344 & 1.170 & 1.919 \\
Significance level & $(0.863)$ & $(0.045)$ & $(0.370)$ & $(0.096)$ \\
\hline \hline
\end{tabular}

Note: Numbers in bold face are $F$-ratios for the ANOVA; numbers in parentheses are the $F$-test significance level.

many new startup businesses which require construction loans and lending to new customers. Lenders in these markets are more likely to claim real estate lending as their primary investment activity, an activity associated with lower loan approval rates for non-farm business loans and a larger geographic market. These markets have more lenders active locally, and non-local financial institutions are becoming increasingly active locally. Though the lenders in these markets do identify a local geographic market, they lend more outside their local market area, perhaps due to their real estate lending focus. It is likely that for certain types of demand growth, the community market is most appropriate, while for other types of demand growth, the county is most appropriate.

ANOVA, using factor (3), Demand Side Business Mix, indicates that neither market grouping is appropriate, which suggests that the lender differences indexed by factor (3) vary by individual lender or by a larger market unit than the county. Lender characteristics measured by factor (3) reflect lending that is limited by borrower characteristics, such as ownership transition stage firms, which are associated with lenders taking more risk and offering easier lending terms. Lenders appear willing to rework loan proposals; however high collateral requirements indicate that lending may be riskier at the margin for these lenders. This evidence suggests that it is not the geographic boundaries of the local market, but, rather, the mix of local business financing opportunities available that cause this behavior. In addition, these lenders are larger, which may allow them to have a broader geographic market.

ANOVA, using factor (4), Supply Side Lending Mix, indicates that the community grouping is statistically significant, while the county grouping is not. High scores on factor (4) reflect growing markets in which borrowers sometimes have difficulty obtaining funds at reasonable interest rates, and lenders are making less effort to expand their market geographically. This reflects lending that is limited by lender policies or characteristics. Though loan approval rates are high and lenders are introducing new product lines, these markets are dominated by lending to businesses in the wholesale (including farm-related businesses) and manufacturing sectors. It is important to note that for analysis of local geographic markets with the supply of credit limited by lenders, a community grouping is more appropriate than the Wisconsin county grouping.

\section{Conclusions}

Analysis of debt capital markets in rural Wisconsin has shown that identifiable "local" markets exist. Lenders recognize local community market boundaries and this spatial grouping results in distinct differences among local debt capital markets. Demand and supply side characteristics of local capital markets appear to be highly correlated and should both be included in any analysis of local capital market behavior. However, the most appropriate geographic unit of analysis for combining demand and supply side characteristics depends on the type of analysis being conducted.

Analysis of capital market behavior in areas with high levels of supply side lending effort can use Wisconsin county size geographic groupings appropriately as proxies for local markets. This grouping will not obscure significant variation among smaller community markets. A high level of lending effort reflected by institutions within these markets appears to depend on institutional specific characteristics rather than local market characteristics. To address capital market issues in these markets, analysis should be conducted at the level of the individual financial institution or with at least a county market area. This result 
may reflect the fact that more aggressive lenders are likely to be lending outside the limited community geographic market and increasing lending competition in a broader area, such as an entire county.

Analysis of capital markets with rapid growth in the demand for credit relative to the supply should use a very small geographic unit of analysis. In Wisconsin, these local areas are community capital markets. Use of larger geographic areas, such as Wisconsin counties, as proxies for local geographic capital markets may frequently obscure local variation, which is "averaged" out in the process of aggregation to the county level.

Analysis of lending, which is limited by the mix of local demand, does not critically depend on local market definitions at either the county or community market level. Multi-county areas or single lending institutions may be the most appropriate unit of analysis.

Analysis of lending, which is limited by the lending emphasis chosen by suppliers, is carried out most appropriately with small geographic markets, such as the community markets identified. These markets tend to have more than one local lender and more non-local lenders active in the market, which allows lending specialization by institution. Though these markets may appear competitive due to the larger number of institutions active locally, lender specialization may lead to less competition within specific categories of lending. In addition to using small geographic markets, analysis of these markets should focus on very narrow definitions of product.

\section{Notes}

${ }^{1}$ The labels for each county type given in quotes are from the USDA county classification scheme by Ross, Peggy J. and Bernal L. Green. Procedures for Developing a PolicyOriented Classification of Nonmetropolitan Counties. Washington, D.C.: U.S. Department of Agriculture, Econ. Res. Serv., EDD Staff Rep. No. AGES850308, August 1985.

${ }^{2}$ Iowa County has a very rapid growth rate in retail sales per capita, while at the same time, retail employment and the number of retail firms has declined. This discrepancy is accounted for by the phenomenal growth over the last decade of a national mail order retailer in the county. These retail sales by the mail order company bias the county per capita sales figure as shown in Table 1.

${ }^{3}$ Though in general it is not appropriate to use dichotomous variables in a factor analysis, their use in this analysis is considered appropriate since the dichotomous variables are not highly correlated and are viewed as measuring continuous variables. The factor score weights are low because standardized scores are used, and many of the variables are dichotomously measured as zero or one (Kim and Meuller, 1978; and Kim, Nie, and Verba, 1977).

\section{References}

Alhadeff, David A. Monopoly and Competition in Banking. Berkeley, Calif.: University of Califomia Press, 1954.

Allardice, David R. A Guide to Banking Markets in the Seventh Federal Reserve District. Chicago: Federal Reserve Bank of Chicago, 1982. and David A. Phillis. An Updated Guide to Banking Markets in the States of the Seventh Federal Reserve District. Chicago: Federal Reserve Bank of Chicago, 1984.

Austin, Douglas V. "Defining the Market Area of a Bank." The Banker's Magazine. (Spring 1969). 64-77. "The Line of Commerce and the Relevant Geographic Market in Banking: What Fifteen Years of Trials and Tribulations Has Taught Us and Not Taught Us About the Measure of Banking Structure." Proceedings of a Conference on Bank Structure and Competition. Chicago: Federal Reserve Bank of Chicago, 1977. 185-209.

Davis, Lance. "The Capital Markets and Industrial Concentration: The U.S. and U.K., a Comparative Study." The Economic History Review. 19:2 (1966). 255-272.

Dreese, G. Richard. "Banks and Regional Economic Development." Southern Economic Journal. 40:4 (April 1974). 647-656.

Ederington, Louis H. and Samuel L. Skogstad. "Measurement of Banking Competition and Geographic Markets: The Market for Checking Account Services." Journal of Money, Credit, and Banking. (August 1977). 469-482.

Edwards, Franklin. "The Banking Competition Controversy." The National Banking Review. (September 1965). 1-34.

Eisenbeis, Robert A. "Local Banking Markets for Business Loans." Journal of Bank Research. (Summer 1971). 30-39.

- "Non-local Banking Markets for Business Loans." Journal of Bank Research. (Winter 1972). $41-47$.

L'Esperance, W. L. The Structure and Control of a State Economy. London: Pion, 1981.

Glassman, Cynthia A. "Banking Markets in Pennsylvania." Changing Pennsylvania's Banking Laws: An Economic Analysis. Philadelphia: Federal Reserve Bank of Philadelphia, 1973.

Heaton, Gary. "1983 Banking Structure in New England." Research Report 68. Boston: Federal Reserve Bank of Boston, 1984.

Hodgman, Donald R. "Competition in Banking and Its Regulation." The Banker's Magazine. (Winter 1964). 46-55.

Holland, Robert C., Tynan Smith, George Hall, and William Paul Smith. "Research Into Banking Structure and Competition." Federal Reserve Bulletin. (November 1964). 1383-1399.

Hoover, E. M. The Location of Economic Activity. New York: McGraw-Hill, 1948. 
Horowitz, Ira. "On Defining the Geographic Market in Section 7 Cases." Proceedings of a Conference on Bank Structure and Competition. Chicago: Federal Reserve Bank of Chicago, 1977. 169-182.

Kaufman, George G. "Bank Market Structure and Performance: The Evidence from Iowa." Southern Economic Journal. (April 1966). 429-439.

Kim, J. O., Nie, and S. Verba. "A Note on Factor Analyzing Dichotomous Variables: The Case of Political Participation." Political Methodology. (1977). 39-62.

Kim, Jae-On and Charles W. Mueller. Factor Analysis: Statistical Methods and Practical Issues. London: Sage Publications, 1978.

King, Frank B. "New Tests of Banking Market Limits." Federal Reserve Bank of Atlanta Monthly Review. (March 1977). 39-40.

Lanzilotti, Robert F. "Banking Structure in Michigan 19451963." Michigan State University Business Studies. Lansing, Mich.: Michigan State University Bureau of Business and Economic Research Division, 1966.

Light, J. O. and W. L. White. The Financial System. Homewood, Ill.: R. D. Irwin, 1979.

Litvak, L. and B. H. Daniels. Innovations in Development Finance. Washington, D.C.: Council of State Planning Agencies, 1979.

Lloyd, P. E. and P. Dicken. Location in Space: A Theoretical Approach to Economic Geography. New York: Harper \& Row, 1972.

Losch, A. The Economics of Location. New Haven, Conn.: Yale University Press, 1954.

Mathis, Stephen A., Duane G. Harris, and Michael Borhlje. "An Approach to the Delineation of Rural Banking Markets." American Journal of Agriculsural Economics. (November 1978). 601-608.

Meyer, J. R!, R. Schmenner, and L. Meyer. Business Location Decisions, Capital Market Imperfections, and Develop- ment of Central City Employment. Cambridge, Mass.: Joint Center for Urban Studies of MTT and Harvard University, 1980.

Meyer, Paul A. "Price Discrimination, Regional Loan Rates, and the Structure of the Banking Industry." Journal of Finance. (March 1967). 37-48.

Osborne, Dale and Jeanne Wendel. The Main Fault with Traditional Research on Banking Competition. Dallas, Texas: Federal Reserve Bank of Dallas, 1978.

Salley, Charles D. "Uniform Price and Banking Market Delineation." Federal Reserve Bank of Atlanta Monthly Review. (June 1975). 86-93.

Schweitzer, Paul R. "The Definition of Banking Markets." Banking Law Journal. (September 1973). 745-762.

Stolz, Richard W. "Local Banking Markets, Structure and Conduct in Rural Areas." Proceedings of a Conference on Bank Structure and Competition. Chicago: Federal Reserve Bank of Chicago, 1976. 134-148.

Straszheim, M. R. "An Introduction and Overview of Regional Money Capital Markets." Essays in Regional Economics. J. Kain and J. Meyer, eds. Cambridge, Mass.: Harvard University Press, 1971.

Sullivan, Timothy G. "The Cost of Capital and the Market Power of Firms." The Review of Economics and Statistics. 60 (1979). 209-217.

Watro, Paul R. "How Should Banking Markets Be Delineated?" Federal Reserve Bank of Cleveland Economic Commentary. (December 1980).

Whitehead, David D. "Relevant Geographic Banking Markets: How Should They Be Defined?" Federal Reserve Bank of Atlanta Economic Review. (January/ February 1980). 20-28.

Wolken, John D. "Geographic Market Delineation: A Review of the Literature." Staff Studies 140 . Washington, D.C.: Federal Reserve System, 1984. 